$10-5-2020$

\title{
Population Council-led partnership influences national and global efforts to end female genital mutilation/cutting
}

Population Council

Follow this and additional works at: https://knowledgecommons.popcouncil.org/

series_newsletters_researchimpact

Part of the International Public Health Commons, and the Women's Health Commons How does access to this work benefit you? Let us know!

\section{Recommended Citation}

"Population Council-led partnership influences national and global efforts to end female genital mutilation/cutting," Research Utilization and Impact Brief. Washington, DC: Population Council, 2020. 


\section{Population Council-led Partnership Influences National and Global Efforts to End Female Genital Mutilation/Cutting}

The Evidence to End FGM/C program has filled critical data gaps, bolstered local capacity, and strengthened stakeholder relationships over the past five years. Through a collaborative, African-led approach, the program informed high-level national policy dialogue in several countries, including Kenya and Nigeria, and contributed to UNFPA's new global estimates of girls at risk for FGM/C.

\section{INTRODUCTION}

Female genital mutilation/cutting $(\mathrm{FGM} / \mathrm{C})^{1}$ is a harmful practice that involves cutting, removing, and sometimes sewing up external female genitalia for nonmedical reasons. While considered a social norm in many cultures, FGM/C is a violation of the rights of girls and women and has no health benefits. It is estimated that more than 200 million girls and women ${ }^{2}$ have undergone FGM/C around the world, and approximately 3.6 million girls are cut each year.

Despite intensified global efforts to eliminate FGM/C since a 2012 UN General Assembly Resolution, critical evidence gaps have hindered a comprehensive, evidence-based response. To help address these gaps, Evidence to End FGM/C:

Research to Help Girls and Women Thrive, ${ }^{3}$ an African-led research consortium, was assembled to generate the high-quality data needed to influence strategic investments, policies, and programs. This five-year project worked in eight African countriesBurkina Faso, Egypt, Ethiopia, Kenya, Nigeria, Senegal, Somalia, and Sudan-to dramatically expand the body of research on the most effective approaches to ending

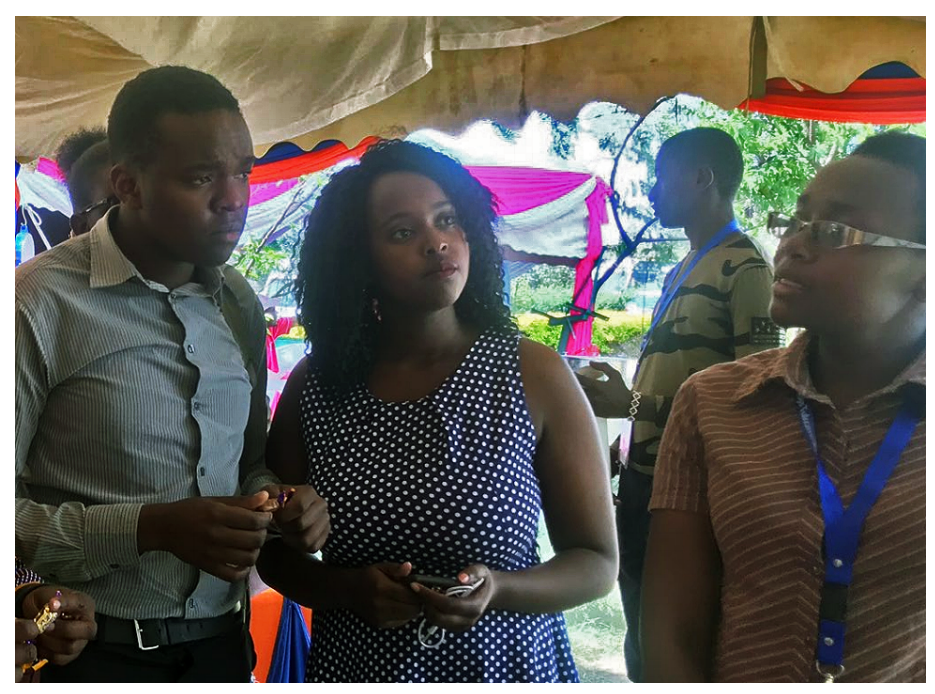

Researchers collaborate at a workshop convened by the Evidence to End FGM/C consortium. (Photo: ( ) Population Reference Bureau)

FGM/C in different contexts. Research was organized around four themes: 1 ) building the evidence base of where, when, and why FGM/C is practiced; 2) assessing a range of interventions to address FGM/C abandonment; 3 ) understanding the wider impacts of FGM/C; and 4) improving research on FGM/C. 
Through the creation of a vibrant South-North research consortium* and 43 studies, the Population Council-led Evidence to End FGM/C program addressed some of the most important challenges in measuring $\mathrm{FGM} / \mathrm{C}$ and provided critical evidence on effective interventions for abandonment. The project produced new data to support decisions about where to target investments; build capacity for utilizing research findings in policies and programs; and strengthen measurement of FGM/C to monitor progress and impacts. Four key lessons are summarized in the box below.
Cross-national, multidisciplinary collaborations brought researchers together to generate highquality evidence to inform policies and programs. The project also applied innovative research methods to improve FGM/C measurement, including geospatial and social network analysis ${ }^{4}$ as well as factorial focus group ${ }^{5}$ approaches. The project expanded the cadre of African researchers with capacity to generate rigorous, timely, and policyrelevant results.

KEY LESSON 1. FGM/C prevalence greatly varies between and within countries, thus understanding the local context of where and when FGM/C is practiced is essential for tailoring investments supporting abandonment efforts.

The prevalence of FGM/C varies almost as much within countries as it does between them. The practice tends to be concentrated in certain subregions and locations due to clustering of practicing ethnic groups; therefore, national data may mask important local variations. Subnational analyses can help programs identify "hot spots"-high prevalence areas that would benefit from tailored interventions.

\section{KEY LESSON 2. The practice of FGM/C and its social and cultural underpinnings are changing.}

The practice of FGM/C is rooted in gender roles, ethnic identity, the power of community influence, and the desire to belong. In 15 countries, the prevalence of FGM/C among girls and women ages 15-19 years is markedly lower than among those ages 45-49 years, providing evidence of a decline in the practice in the younger generation.

KEY LESSON 3. The health sector can and should play a central role in preventing and responding to FGM/C.

Across countries where FGM/C is practiced, traditional cutters are the main providers, but medicalizationcutting by a doctor, nurse, or trained midwife-is increasingly common in some places. Many health care systems do not have the policies, resources, capacity, or documentation needed to prevent FGM/C and support women experiencing complications.

\section{KEY LESSON 4. Laws are important but require social legitimacy to be effective.}

Laws banning FGM/C have existed for decades, but the public may be unaware of them or choose to ignore them, and they may not be enforced. Legal prohibitions of FGM/C may promote abandonment of the practice or may drive it underground. It is critical to address inherent conflicts between formal laws prohibiting FGM/C and religion and customs, which are also recognized as sources of law.

\footnotetext{
* Consortium partners include: the Africa Coordinating Centre for the Abandonment of Female Genital Mutilation/Cutting (ACCAF) at the University of Nairobi; the Global Research and Advocacy Group (GRAG), Dakar; Population Reference Bureau (PRB); MannionDaniels Ltd.; Northumbria University, United Kingdom; the Ethiopian Society of Sociologists, Social Workers and Anthropologists (ESSSWA), Ethiopia; Dr. Gerry Mackie of the University of California, San Diego; and Dr. Bettina Shell-Duncan of the University of Washington, Seattle.
} 


\section{KEY IMPACTS}

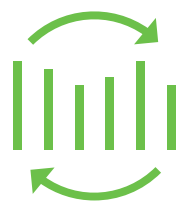

INNOVATIVE ANALYSIS OF EXISTING DATASETS ON FGM/C RISK INFORMED UNFPA PROGRAMMING AND GLOBAL ESTIMATES

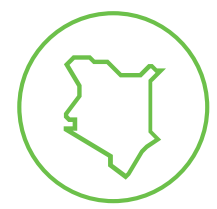

IN KENYA, CONTRIBUTED TO ACTIVITIES OF THE ANTI-FGM BOARD AND UNFPA-UNICEF JOINT PROGRAMME ON FGM/C

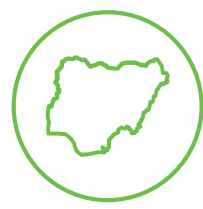

IN NIGERIA, CONTRIBUTED TO NATIONAL POLICIES, INCLUDING GUIDANCE ON ENDING THE PRACTICE OF FGM/C

\section{RESEARCH USE AND IMPACT}

Through strategic engagement of decision-makers at all stages of the research process, the Evidence to End FGM/C consortium has gained recognition as an important, credible resource to inform evidence-based FGM/C policies and programming. The project used innovative multilevel analysis of existing Demographic and Health Survey (DHS) and Multiple Indicator Cluster Surveys (MICS) datasets to determine the prevalence and the changing nature of FGM/C in Kenya, Nigeria, and Senegal. The consortium worked closely with UNFPA to estimate actual survival trends and generate age-specific risks of being cut, allowing for comparisons between countries. This work has informed UNFPA's programming decisions at the national level and contributed to UNFPA's new global estimates of girls at risk for FGM/C.

Strong country-level presence also provided a platform for networking and sustaining relationships with key partners and stakeholders. In Kenya, the project developed and strengthened its partnership and collaboration with the country's Anti-FGM Board and the United Nations Joint Programme (UNJP) in Nairobi, regularly presenting and discussing the implications of evidence from its work at their meetings. The Anti-FGM Board, the primary government body responsible for implementing the Prohibition of FGM Act, actively sought out support from the Council to inform its activities. In addition, the project was invited to contribute to the Joint Evaluation of the UNJP on FGM in Kenya, the UNJP annual FGM/C review and planning meetings, the Board's capacity assessment, and the Board's annual strategic planning.

In Nigeria, the consortium's results highlighting the importance of collecting FGM/C data at community and facility levels, including evidence from recently completed studies such as "Diagnostic assessment of the health systems response to FGM/C management and prevention" ${ }^{6}$ and "Understanding medicalisation of FGM/C in Nigeria,"7 have been referenced in high-level political discussions. The team participated in quarterly meetings with DFID FGM/C implementing partners, the UNJP, the Girl Generation, and government representatives (the Federal Ministry of Health and the Federal Ministry of Women Affairs) to discuss ongoing work and its relationship to local and national abandonment programs and policies. Through these ongoing engagements, in 2019, the consortium was invited to contribute to the development and revision of national policies, including guidelines on ending the practice of $\mathrm{FGM} / \mathrm{C}$ and addressing gender in health.

\section{LOOKING FORWARD}

The Council continues to provide leadership for FGM/C research and evidence uptake, heading the FGM Data Hub as part of DFID's support to the second phase of the Africa-Led Movement to End Female Genital Mutilation. The FGM Data Hub is a collaborative, targeted program to improve data use and strengthen monitoring and measurement tools for evidence-based FGM intervention design and implementation. The Council is also working together with UNJP to develop a global research and evidence-based action agenda for the next decade to accelerate progress toward elimination of FGM/C.

For more information, please visit Evidence to End FGM/C: Research to Help Girls and Women Thrive. 


\section{SELECTED RESOURCES}

\begin{tabular}{|c|c|}
\hline $\begin{array}{l}\text { Documenting the } \\
\text { Consortium's } \\
\text { Approach and } \\
\text { Impact to Date }\end{array}$ & $\begin{array}{l}\text { Report: Reflections from Five Years of Research } \\
\text { Video: Reflections from Five Years of Research } \\
\text { Presentation: End of Programme Webinar Series: Using Research to Understand and Accelerate } \\
\text { Abandonment of FGM/C }\end{array}$ \\
\hline $\begin{array}{l}\text { Evidence: } \\
\text { Understanding } \\
\text { Local Variations }\end{array}$ & $\begin{array}{l}\text { Evidence Brief: Understanding Local Variation in How Female Genital Mutilation/cutting declines, } \\
\text { changes, or persists: Analysis of household survey data for Kenya, Nigeria, and Senegal } \\
\text { Report: Female Genital Mutilation/Cutting in Senegal: Is the Practice Declining? Descriptive Analysis } \\
\text { of Demographic and Health Surveys, 2005-2017 } \\
\text { Evidence Brief: Using Demographic and Health Surveys in the Campaign to End FGM/C: A Kenyan } \\
\text { Example }\end{array}$ \\
\hline $\begin{array}{l}\text { Evidence: } \\
\text { Changes in } \\
\text { Social and } \\
\text { Cultural } \\
\text { Underpinnings }\end{array}$ & $\begin{array}{l}\text { Report: Understanding female genital mutilation/cutting abandonment in Egypt } \\
\text { Report: Tracing Change in FGM/C through Social Networks: An Intersectional Analysis of the Influ- } \\
\text { ence of Gender, Generation, Status and Structural Inequality in Senegal } \\
\text { Report: Exploring changes in FGM/C: Shifting norms and practices among communities in Fafan and } \\
\text { West Arsi zones, Ethiopia } \\
\text { Report: Medicalisation of Female Genital Mutilation/Cutting in Sudan: Shifts in Types and Providers }\end{array}$ \\
\hline $\begin{array}{l}\text { Evidence: Role of } \\
\text { Health System }\end{array}$ & $\begin{array}{l}\text { Journal Article: Exploring the capacity of the Somaliland healthcare system to manage female genital } \\
\text { mutilation/cutting-related complications and prevent the medicalization of the practice: A cross- } \\
\text { sectional study } \\
\text { Web Feature: Understanding the Impact of Medicalisation on Female Genital Mutilation/Cutting } \\
\text { Evidence Brief: A Diagnostic Assessment of the Health System's Response to FGM/C Management } \\
\text { and Prevention in Nigeria }\end{array}$ \\
\hline $\begin{array}{l}\text { Evidence: Role of } \\
\text { Legal System }\end{array}$ & $\begin{array}{l}\text { Policy Brief: When and how the law is effective in reducing the practice of } \\
\text { FGM/C: A cross-border study in Burkina Faso and Mali } \\
\text { Report: Assessing the Role of Law in Reducing the Practise of FGM/C in Kenya }\end{array}$ \\
\hline
\end{tabular}

\section{NOTES}

1 Female genital mutilation. who.int/en/news-room/fact-sheets/detail/ female-genital-mutilation.

2 A state-of-the-art synthesis on female genital mutilation/cutting: What do we know now? knowledgecommons.popcouncil.org/departments_sbsr$\mathrm{rh} / 633 /$

3 Evidence to end FGM/C: Research to help girls and women thrive. popcouncil.org/research/evidence-to-end-fgm-c-research-to-help-girlsand-women-thrive1/.

${ }^{4}$ Reference guide for Data Collection: Qualitative social network interviews. knowledgecommons.popcouncil.org/departments_sbsr-rh/720/

${ }_{5}$ Reference guide for factorial focus group analysis methods for studying social norm change. knowledgecommons.popcouncil.org/departments_ sbsr-rh/721/

6 A diagnostic assessment of the health system's response to FGM/C management and prevention in Nigeria. knowledgecommons. popcouncil.org/departments_sbsr-rh/1081/

7 Understanding medicalisation of FGM/C: A qualitative study of parents and health workers in Nigeria. knowledgecommons.popcouncil.org/ departments_sbsr-rh/1081/

Funding for the programme was from UK Aid from the UK government for the benefit of developing countries. However, the views expressed and information contained are not necessarily those of, or endorsed by the UK government, which can accept no responsibility for such views or information or for any reliance placed on them.

The Population Council collaborates with program implementers, policymakers, researchers, and funding partners to advance evidence-based solutions to critical health and development challenges. The Council's research impact briefs feature recent highlights of our ongoing work to ensure evidence is translated into meaningful actions at community, national, regional, and global levels to improve lives around the world.

Recommended citation: "Population Council-led Partnership Influences National and Global Efforts to End FGM/C," Research Utilization and Impact Brief. Washington, DC: Population Council, 2020. 